\title{
STRESS RELAXATION CHARACTERISTICS OF SATURATED CLAYS
}

\author{
Yoshiaki Oda ${ }^{\mathrm{i})}$ and Toshiyuki Mitachi ${ }^{\mathrm{i} i)}$
}

\begin{abstract}
A series of undrained triaxial stress relaxation tests on four saturated remoulded clays consolidated under isotropic stress condition were performed to investigate the influence of imposed strain level and strain rate prior to the start of relaxation test on the principal stress difference and pore pressure versus elapsed time relationships.

Experimental results show that the principal stress difference versus logarithm of time relationship is approximated by the two straight lines independent of strain level, strain rate and mode of stress application in the preceding undrained shear process, and that the stress state corresponding to the point of intersection of the two straight lines locates close to the effective stress path calculated by the Cam-clay model proposed by Roscoe et al. (1963). A sign that the principal stress difference finally approaches to a limiting equilibrium value is found from the test results. It is also shown that the stress points corresponding to the equilibrium state lie below the Cam-clay effective stress path and the curve linking these stress points makes a similar shape of the path. The slope of the initial straight line on the principal stress difference versus logarithm of time plot depends on the magnitude of strain imposed in the preceding undrained shear process. Plastic component of the change of pore water pressure, which was defined by Lo (1969), during stress relaxation test depends not only on the strain level but also on the strain rate prior to the test.
\end{abstract}

Key words : clay, consolidated undrained shear, dilatancy, effective stress, pore pressure, relaxation, stress path, time effect, triaxial compression test (IGC:D6/D 5)

\section{INTRODUCTION}

Great effort has so far been devoted to clarify the time effect such as strain rate, undrained creep, secondary compression and stress relaxation on the stress-strain behavior of cohesive soils. When overall time dependent behavior is considered, it is important to take into account the static stress state at which the strain rate to be zero. Not only clear definition has not yet been given on this state but also the experimental confirmation is not sufficient up to the present. Although research works on the stress relaxation tests on clay, in which external strain rate is controlled to be zero, are not so many

i) Research Associate, Department of Civil Engineering, Hokkaido University, Sapporo, Hokkaido.

ii) Professor, Department of Civil Engineering, Hokkaido University, Sapporo, Hokkaido. Manuscript was received for review on February 10, 1988.

Written discussions on this paper should be submitted before July 1, 1989, to the Japanese Society of Soil Mechanics and Foundation Engineering, Sugayama Bldg. $4 \mathrm{~F}$, Kanda Awaji-cho 2-23, Chiyoda-ku, Tokyo 101, Japan. Upon request the closing date may be extended one month. 
compared to the works on other time dependent behavior of clay, most of the researchers have reported that the principal stress difference decreases linearly with the logarithm of time.

Murayama and Shibata (1961) performed a series of undrained relaxation tests and reported that the stress decreased linearly with the logarithm of time and approached to a limiting equilibrium value.

Test results by Vialov and Skibitsky (1961) do not exhibit such an equilibrium value within the test duration of about $400 \mathrm{mi}^{-}$ nutes.

Wu et al. (1962) performed a series of stress relaxation tests on three samples of a remoulded natural clay. Stress relaxation was started after a constant rate of strain $(0.05 \%$ min) loading. The data show no apparent sign of existence of limiting principal stress difference at least up to 24 hours.

Christensen and $\mathrm{Wu}(1964)$ reported stress relaxation test results showing no sign of existence of limiting stress within the oneday duration of the experiments in contrast to the fact that the stress versus time curve calculated by their equation based on the theory of rate process requires the termination of the stress relaxation at a limiting value.

Based on the results of relaxation test under undrained triaxial compression, Murayama and Shibata (1964) showed that the change of pore water pressure during the tests was practically zero and the slope of the linear portion of the stress versus logarithm of time curve for a given initial strain of $1 \%$ was independent of confining pressure, and it increased with initial imposed strain.

Lacerda and Houston(1973) performed a series of stress relaxation tests on four clays. Although the tests were continued up to 200 to 1000 minutes, no sign of the existence of a limiting equilibrium stress was found. They reported that the ratio of the principal stress difference at any time to the stress at the beginning of stress relaxation was linear with the logarithm of time and the slope was independent of confining pressure, and the intercept of the straight line on the time axis gave a time $t_{0}$ which was dependent solely on the strain rate prior to the relaxation test for a given soil type. They also found that the change of pore pressure during the test was very small.

Akai et al. (1975) performed stress relaxation tests on two remoulded saturated clays varying the consolidation pressure, strain rate and strain level prior to the test. They found that the slope of the straight lines on the principal stress difference versus logarithm of time plot was independent of consolidation pressure and strain rate, and it was dependent solely on the initial strain and became constant value above $1 \%$ of strain for the clay. Their data exhibit no sign of the existence of a limiting value for about 10000 min. duration of the experiments. They also found that pore water pressure change did not take place during the stress relaxation period and that the final effective stress state reached below the "static stress path" given by Cam-clay model of Rescoe et al. (1963).

Arai (1985) performed a series of stress relaxation tests on a remoulded clay after undrained shear with two kinds of strain rate. Test results show that the effective stress path during relaxation goes inside of the static stress path as pointed out by Akai et al. (1975). Pore pressure during relaxation is almost constant for small strain rate loading prior to the start of relaxation test, and for large strain rate, it increases at the beginning of the test and becomes constant thereafter. He explained the reason of this behavior as that it is due to the equalization of unequal pore pressure distribution which has occurred at the preceding constant strain rate shear process.

As shown above, all the researchers reached to the same conclusion that the principal stress difference decreases proportionally to the logarithm of elapsed time. Existing stress relaxation test results, however, show divergence concerning to the existence of a limiting equilibrium stress. Consistent conclusion has not yet been obtained on the pore pressure behavior during stress relaxation. 
Most of the experimental investigations mentioned above were performed within 24 hours. Longer period of experiment is needed to confirm the existence of the limiting equilibrium stress.

In this paper, the effect of imposed strain level and strain rate prior to the stress relaxation test on the behavior of principal stress difference and pore pressure during the test is investigated.

\section{EXPERIMENT}

\section{Clays Tested and Specimen Preparation}

Samples tested are four remoulded clays. Two of them, Kaolin and Kasaoka clay are on the market. Hayakita and Kucchan clay are natural clays sampled in the suburbs of Hayakita and Kucchan Town in Southwestern part of Hokkaido Island. Kaolin and Kasaoka clay, which were in the state of powder, mixed with distilled water to have the water content of twice the liquid limit of each sample and stored in the state of slurry. Two natural clays were thoroughly mixed with distilled water, sieved by a 420 $\mu \mathrm{m}$ size sieve and stored in the state of slurry.

Index properties of these four samples after these process, which are called as Sample A, $\mathrm{B}, \mathrm{C}$ and $\mathrm{D}$ respectively from now on, are shown in Table 1 . Before making test specimen, the slurry was stirred again in a soil mixer for about two hours and then transferred under a vacuum to a preconsolidation cell, the diameter and the height of which are $200 \mathrm{~mm}$ and $400 \mathrm{~mm}$, respectively. The slurry was initially consolidated one-dimensionally under vertical consolidation pressure of $100 \mathrm{kPa}$ for Sample A and $80 \mathrm{kPa}$ for other samples. After consolidation (ten days for Sample A, two weeks for Sample B, seven

Table 1. Index properties of samples

\begin{tabular}{|c|c|c|c|c|c|}
\hline \multicolumn{2}{|r|}{ Sample } & $\begin{array}{l}\text { Liquid } \\
\text { Limit }(\%)\end{array}$ & $\begin{array}{l}\text { Plastisity } \\
\text { Index }\end{array}$ & $\mid \begin{array}{l}\text { Specific } \\
\text { Gravity }\end{array}$ & $\underset{<5 \mu \mathrm{m} \quad(\%)}{\text { Clay Fraction }}$ \\
\hline A & Kaolin & 76 & 44 & 2.75 & 99 \\
\hline B & Kasaoka & 62 & 25 & 2.77 & 45 \\
\hline $\mathrm{C}$ & Hayakita & 63 & 30 & 2.65 & 60 \\
\hline $\mathbf{D}$ & Kucchan & 81 & 41 & 2.68 & 77 \\
\hline
\end{tabular}

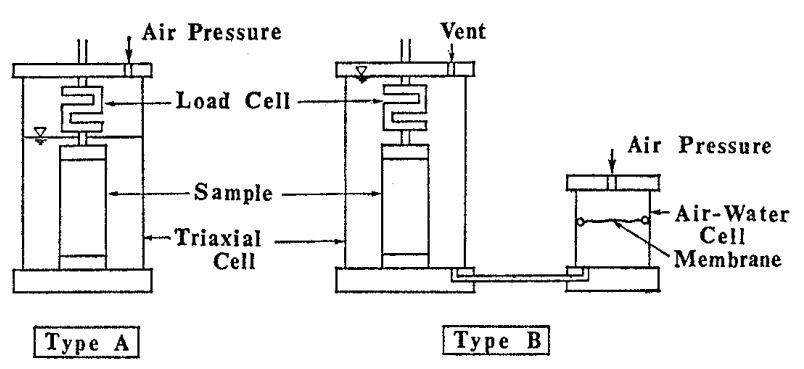

Fig. 1. Types of triaxial cell used in the test

and eight days for Sample C and D, respectively), cylindrical specimens for triaxial tests, $50 \mathrm{~mm}$ in diameter and $120 \mathrm{~mm}$ in height, were trimmed vertically for Sample A and horizontally for Sample B, C and D from the preconsolidated sample.

Test specimens of Sample B, C and D were set up to the triaxial cell base under water with $0.2 \mathrm{~mm}$ thick double membrane and the specimen of Sample A was set up in the air with single membrane. The drainage during isotropic consolidation was forced to radial direction through the filter paper wrapped around the specimen. A sheet of membrane with silicone grease was inserted between specimen and loading cap and pedestal, respectively to minimize the friction between them. Pore pressure was measured at the bottom of the specimen by pressure transducer, and axial load measured by load cell set up inside the triaxial cell as shown schematically in Fig. 1 . The rigidity of the load cell was $6 \times 10^{-4} \mathrm{~mm} / \mathrm{kgf}\left(6.1 \times 10^{-5} \mathrm{~mm} /\right.$ $N)$ and was judged that the axial strain development on the specimen due to the deflection of the load cell could be negligible.

In the triaxial test continuing for a long period, great care must be taken on the problem of leakage through pore pressure routes, drainage routes and that through rubber membrane. In the present authors' laboratory, $100 \%$ glycerin, which is less air entrained, has been used as a cell fluid for a short term tests such as conventional consolidated undrained triaxial tests. It has been known that when glycerin is used as the cell fluid, the water in the specimen migrates through membrane to the cell fluid because of the 


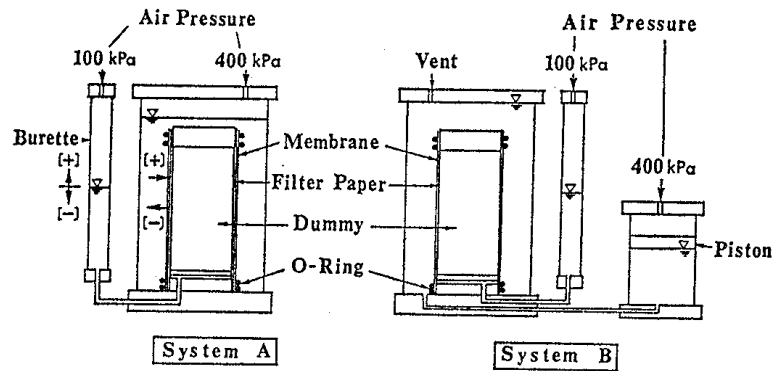

(a) System of testing

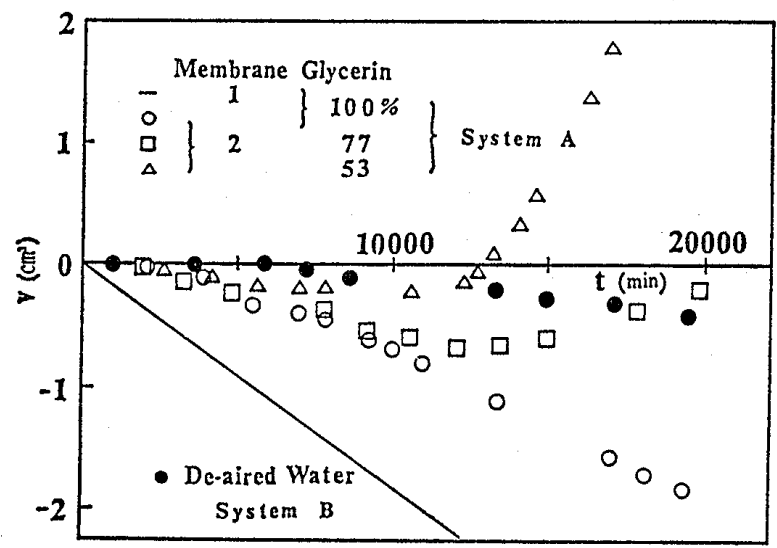

(b) Test result

Fig. 2. Osmotic water migration test

osmotic pressure between the water within the filter paper wrapped around the specimen and the cell fluid. For drained test, observed volume change can be corrected by the volume of migration obtained from predetermined calibration curve. For long term undrained stress relaxation test, however, the water migration from the specimen toward the cell fluid will induce a small volumetric strain, which in turn might give an influence on the axial stress of the specimen. Therefore, osmotic migration test using dummy specimen with $0.2 \mathrm{~mm}$ thick double membrane and variable concentration of glycerin as cell fluid was performed by using System A in Fig. 2(a). Test results are shown in Fig. 2(b). Volume of water migration from specimen toward the cell fluid is represented as negative. Concentration of Glycerin is represented by percent in mass. It is seen from this figure that the use of double membrane decreases the volume of migration from the specimen toward the cell fluid to be about two thirds of that for single membrane and that low concentration of glycerin leads to less migration. In $53 \%$ concentraion, however, initial negative migration changes to be positive at about seven days after the start of test due probably to the worsen of the membrane, and migration from the cell fluid toward the specimen is observed. In $77 \%$ concentration, it is seen that the change of the volume of migration to be zero in between 10000 minutes through 15000 minutes after the start of test. Water migration test with single membrane and de-aired water as cell fluid was also performed by using the System B in Fig. 2(a). Test result is shown as solid circle in Fig. 2(b). The volume of water migration can be negligible for the test period lasting about two weeks.

In these circumstances, $77 \%$ concentration of glycerin was used as cell fluid for the tests on Sample B, C and D with the triaxial cell of type A shown in Fig. 1, in which the test period lasting five to eleven days.

For the test on Sample A, triaxial cell of type B shown in Fig. 1 was used with de-aired water as cell fluid and carefully sealed load cell. In this type of triaxial cell, it was confirmed that the water migration could be negligible for test duration of up to seven days.

\section{Testing Procedure}

Specimens are first consolidated under iso-

Table 2. Conditions of specimen preparation and isotropic consolidation process

\begin{tabular}{|c|c|c|c|c|c|}
\hline \multicolumn{2}{|c|}{ Sample } & A & B & $\mathrm{C}$ & $\mathrm{D}$ \\
\hline \multirow{3}{*}{$\begin{array}{l}\text { Preconsolidation } \\
\text { Process }\end{array}$} & $\sigma_{v}(\mathrm{kPa})$ & 100 & \multicolumn{3}{|c|}{80} \\
\hline & Period(day) & 10 & 14 & 7 & 8 \\
\hline & Trimming & $\mathrm{V}$ & \multicolumn{3}{|c|}{$\mathrm{H}$} \\
\hline \multicolumn{2}{|c|}{ Method of Setting } & In the $\mathrm{Air}$ & Und & $\begin{array}{l}\text { er } \\
\text { Wate }\end{array}$ & \\
\hline \multicolumn{2}{|l|}{ Membrane } & Single & \multicolumn{3}{|c|}{ Double } \\
\hline \multicolumn{2}{|l|}{ Cell Fiuid } & $\begin{array}{l}\text { De-Aired } \\
\text { Water }\end{array}$ & \multicolumn{3}{|c|}{$\begin{array}{l}\text { G1ycerin } \\
\text { (77\% Conc.) }\end{array}$} \\
\hline \multicolumn{2}{|c|}{ Type of Triaxial Cell (Fig. 1) } & B & \multicolumn{3}{|c|}{ A } \\
\hline \multicolumn{2}{|c|}{ Back Pressure (kPa) } & 200 & \multicolumn{3}{|c|}{100} \\
\hline \multirow{4}{*}{$\begin{array}{l}\text { Isotropic } \\
\text { Consolidation } \\
\text { Process }\end{array}$} & Period (day) & 1 & 5 & & 1 \\
\hline & Number of Steps & 5 & \multicolumn{3}{|c|}{1} \\
\hline & Judgement & $\log t$ & \multicolumn{3}{|c|}{$3 t$} \\
\hline & $p_{c}(\mathrm{kPa})$ & \multicolumn{4}{|c|}{300} \\
\hline
\end{tabular}


tropic stress condition with initial back pressure of $200 \mathrm{kPa}$ for Sample A and $100 \mathrm{kPa}$ for other three samples. In Sample A, isotropic consolidation stress was increased in five steps to a final value of $300 \mathrm{kPa}$. In other three samples, consolidation stress of $300 \mathrm{kPa}$ was applied in one step. After completion of primary consolidation(judgment of completion of primary consolidation was done by $\log t$ method for Sample $A$ and $3 t$ method -JSSMFE (1979)- for other three samples), specimen was sheared to a prescribed strain level under undrained compression by increas-

Table 3. Conditions for undrained loading prior to the relaxation test

\begin{tabular}{|c|c|c|c|c|}
\hline Sample & No. & $\varepsilon(\%)$ & $\dot{\varepsilon}(\% / \mathrm{min})$ & $\begin{array}{c}\text { Method of Stress } \\
\text { Application }\end{array}$ \\
\hline \multirow{13}{*}{ A } & 11 & 0.53 & & \multirow{13}{*}{ Constant Rate of Strain } \\
\hline & 12 & 0.97 & & \\
\hline & 13 & 2.06 & 0.1 & \\
\hline & 14 & 4.52 & & \\
\hline & 15 & 0.30 & & \\
\hline & 28 & 0.13 & & \\
\hline & 29 & 3. 16 & & \\
\hline & 201 & 3.44 & & \\
\hline & 202 & 2.81 & 0.05 & \\
\hline & 203 & 0.69 & & \\
\hline & 204 & 0.53 & & \\
\hline & 205 & 1.84 & & \\
\hline & $\begin{array}{l}31 \\
32 \\
34 \\
35 \\
36\end{array}$ & $\begin{array}{l}0.44 \\
0.92 \\
1.97 \\
0.33 \\
3.28\end{array}$ & 0.01 & \\
\hline \multirow{3}{*}{ B } & $\begin{array}{l}11 \\
21 \\
31 \\
\end{array}$ & $\begin{array}{l}0.61 \\
1.51 \\
2.44 \\
\end{array}$ & $\begin{array}{l}0.01 \\
0.02 \\
0.02\end{array}$ & $\begin{array}{l}\text { Constant Rate of Stress } \\
(\Delta q / \Delta t \fallingdotseq 0.6 \mathrm{kPa} / \mathrm{min})\end{array}$ \\
\hline & $\begin{array}{l}12 \\
32 \\
42 \\
13 \\
23 \\
14 \\
24\end{array}$ & $\begin{array}{l}1.62 \\
0.52 \\
2.49 \\
2.57 \\
0.53 \\
1.50 \\
6.21\end{array}$ & $\begin{array}{l}0.09 \\
0.05 \\
0.05 \\
0.003 \\
0.005 \\
0.05 \\
0.05\end{array}$ & Constant Rate of Strain \\
\hline & $\begin{array}{l}33 \\
43 \\
34 \\
44\end{array}$ & $\begin{array}{l}2.97 \\
0.61 \\
0.31 \\
2.29\end{array}$ & $\begin{array}{l}0.001 \\
0.0001 \\
0.0006 \\
0.003 \\
\end{array}$ & $\begin{aligned} q / q_{\max } & =70 \%, t=560 \mathrm{~min} \\
q / q_{\max } & =30 \%, t=690 \mathrm{~min} \\
q / q_{\max } & =25 \%, t=150 \mathrm{~min} \\
q / q_{\max } & =70 \%, t=150 \mathrm{~min}\end{aligned}$ \\
\hline $\mathrm{C}$ & $\begin{array}{l}2 \\
3 \\
4\end{array}$ & $\begin{array}{l}1.78 \\
0.94 \\
0.45\end{array}$ & 0.05 & Constant Rate of Strain \\
\hline $\mathrm{D}$ & $\begin{array}{l}1 \\
2 \\
3 \\
4\end{array}$ & $\begin{array}{l}4.55 \\
2.11 \\
1.11 \\
0.50\end{array}$ & 0.05 & Constant Rate of Strain \\
\hline
\end{tabular}

ing axial stress while lateral stress was maintained constant. After reached the prescribed axial strain, relaxation test was started by stopping the motor of the testing apparatus and fixing the movement of the axial loading piston to the top plate of the triaxial cell. Temperature of laboratory during the test was controlled at $20 \pm 0.5^{\circ} \mathrm{C}$.

Conditions of the preconsolidation process, type of triaxial cell, magnitude of back pressure, conditions of isotropic consolidation process etc. for each sample are tabulated in table 2.

Application of principal stress difference was performed by strain controlled method (constant rate of strain) for the major part of tests. For Sample B, two more types of stress application method were adopted in order to study the influence of mode of stress application on the relaxation behavior. One of which is to apply the principal stress difference $q\left(=\sigma_{1}-\sigma_{3}\right)$ in constant rate and the other one is the method to apply the prescribed constant stress for some period of time (creep loading). Method of stress application, strain level and rate of strain prior to the relaxation test are shown in Table 3. Strain rate for undrained shear with constant rate of stress and that for undrained creep prior to the stress relaxation test shown in Table 3 are calculated with the time required to attain the magnitude of axial deformation corresponding to $0.02 \%$ of axial strain at the start of the relaxation test.

Although there are some examples of stress relaxation test which were performed repeatedly on the same specimen with different strain level (e. g. Lacerda and Houston (1973) and Arai (1985)), relaxation test in this paper was limited to once for each specimen, taking into account the structural change of the clay after the stress relaxation. Each relaxation test was continued at least 3000 minutes for Sample A, 5000 minutes for Sample C and D, and 8000 minutes for Sample $B$, respectively. 


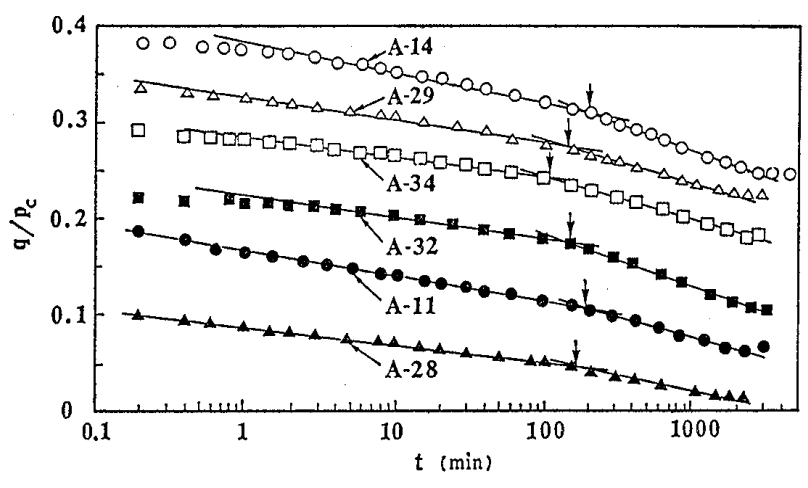

(a) Sample $\mathbf{A}$

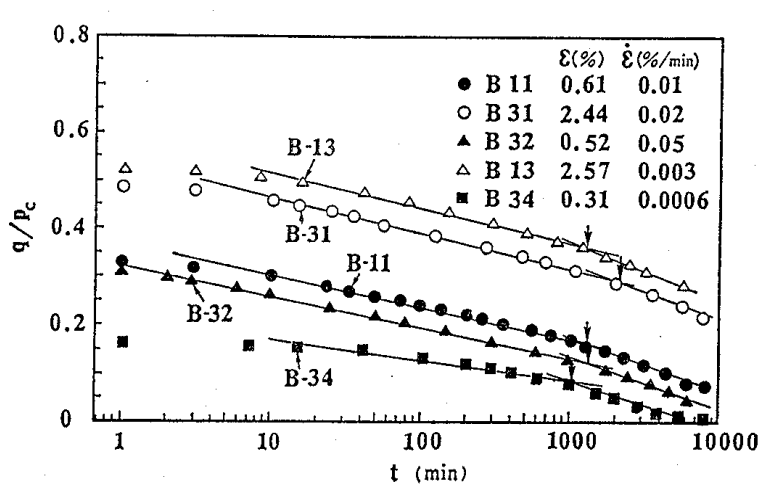

(b) Sample B

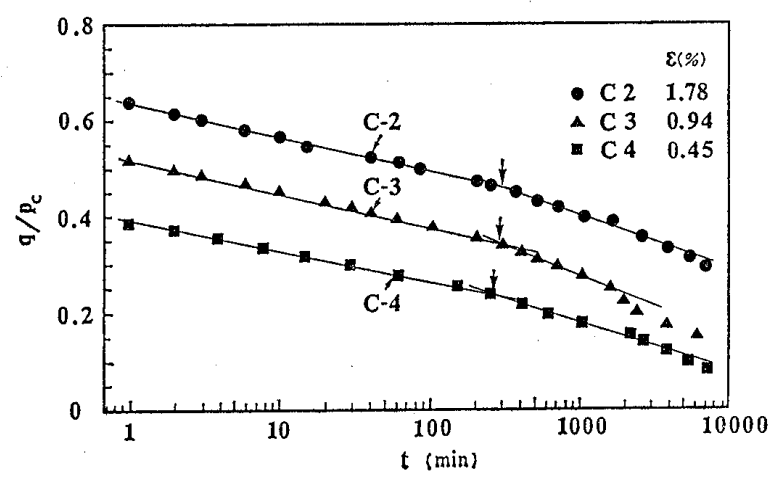

(c) Sample C

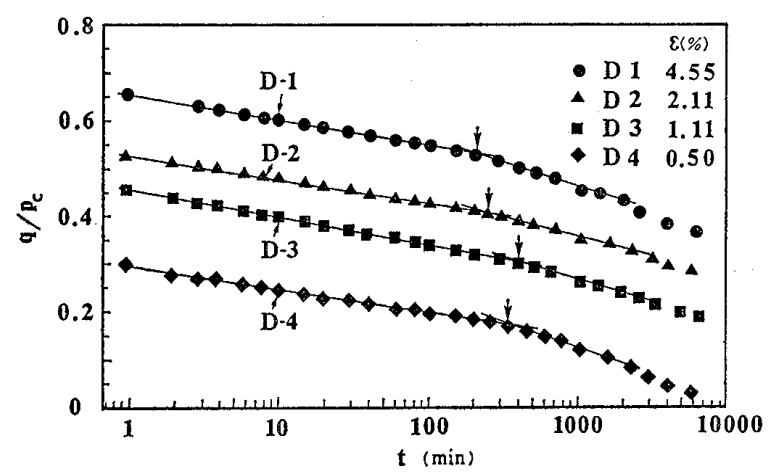

(d) Sample D

Fig. 3. Stress relaxation curves

\section{TEST RESULTS AND DISCUSSION}

Principal Stress Difference versus Time Relationship

Fig. 3 illustrates the principal stress difference normalized by the consolidation pressure $p_{c}$ versus logarithm of time relationship during the test for four samples. As can be seen from this figure, principal stress difference decreases linearly with logarithm of time, from the start of test to some particular time, irrespective of the difference of stress application method, imposed strain level and strain rate prior to the relaxation test. Each stress relaxation curve has an inflection point at a certain time, which is somewhat different in each clay sample, and the principal stress difference versus logarithm of time is approximated by two straight lines. This behavior does not depend on the mode of stress application, imposed strain level and the rate of strain in the preceding undrained loading process. The time $t_{s}$ corresponding to the inflection point in Fig. 3 is different for different clay samples. The values of $t_{s}$ mentioned above are tabulated for four samples in Table 4 with the time $t_{100}$ obtained from the isotropic consolidation stage by $\log t$ method. As seen in the table, $t_{s}$ is longer for the sample having longer $t_{100}$. Generally speaking, $t_{100}$ for the soil exhibiting high permeability is short. Assuming that the stress relaxation occurs due mainly to the reorientation of the clay particles, the time required for the occurrence of the reorientation may be shorter for the soil having high permeability.

It is interesting whether the clays have a limiting equilibrium stress in the relaxation process. From the results of this test program, Sample A shows the trend of having the limiting value and the time corresponding to the state is about 3000 to 5000 minutes.

Table 4. Relationship between $\boldsymbol{t}_{s}$ and $\boldsymbol{t}_{100}$

\begin{tabular}{l|l|r|r}
\hline \multicolumn{2}{c|}{ Sample } & \multicolumn{1}{|c|}{$t_{s}(\min )$} & \multicolumn{1}{|c}{$t_{100}(\mathrm{~min})$} \\
\hline A & Kaolin & $80 \sim 200$ & $60 \sim 80$ \\
B & Kasaoka & $900 \sim 2200$ & $1500 \sim 3000$ \\
C & Hayakita & $120 \sim 300$ & $250 \sim 300$ \\
D & Kucchan & $200 \sim 400$ & $250 \sim 300$ \\
\hline
\end{tabular}




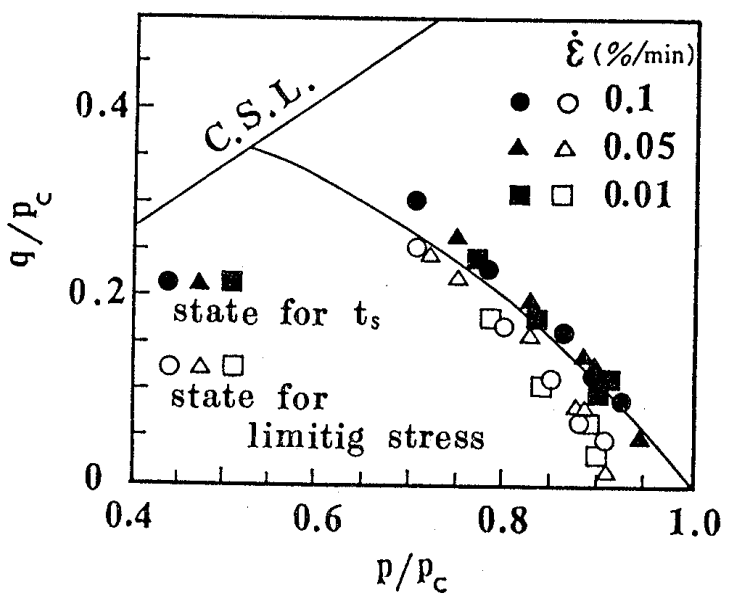

(a) Sample A

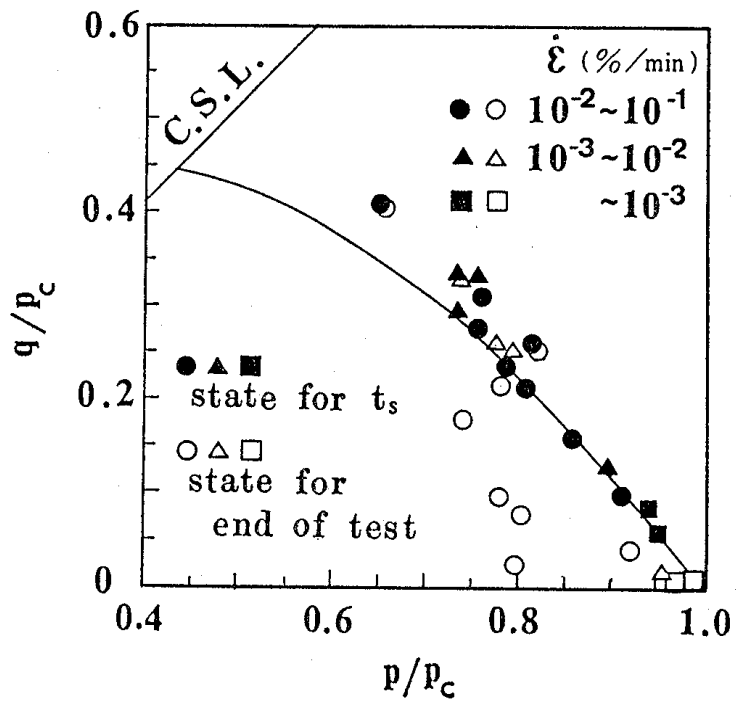

(b) Sample B

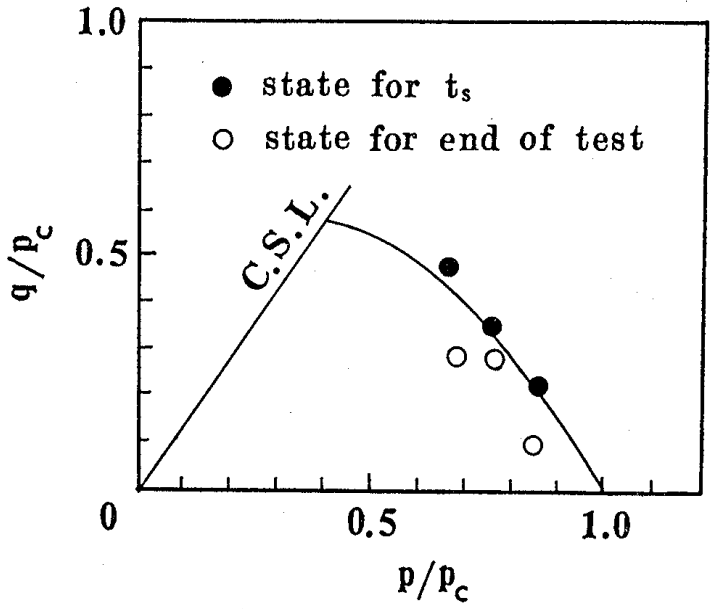

(c) Sample C

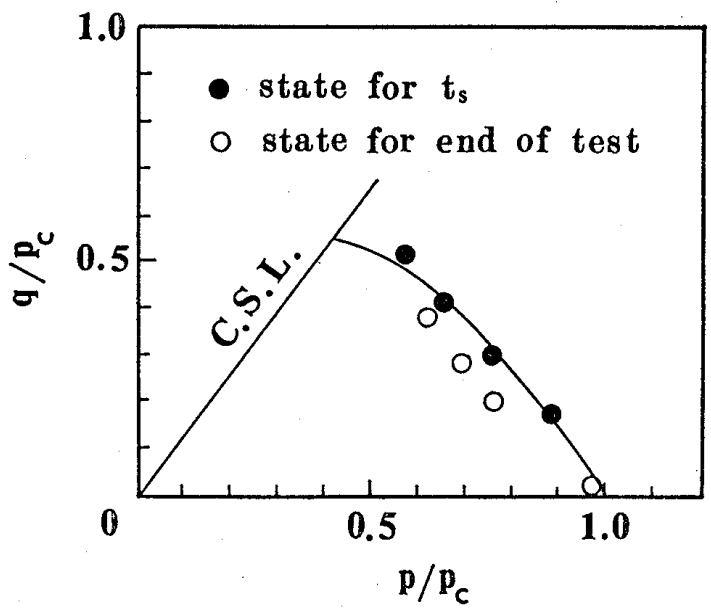

(d) Sample D

Fig. 4. Effective stress state corresponding to the time $t_{s}$

As the time $t_{s}$ of Sample A, which shows a sign of the existence of a limiting equilibrium stress, is not short comparing to other three clays, those clays might exhibit the existence of the limiting stress if the tests have been continued longer.

Fig. 4 illustrates the stress states corresponding to that for $t_{s}$ and that for the end of test on $p-q$ stress plane, where $p$ and $q$

Table 5. Parameters used for calculation of Cam-clay effective stress path

\begin{tabular}{c|l|c|c|c}
\hline \multicolumn{2}{c|}{ Sample } & $M$ & $\lambda$ & $\kappa$ \\
\hline A & Kaolin & 0.69 & 0.225 & 0.070 \\
B & Kasaoka & 1.03 & 0.210 & 0.040 \\
C & Hayakita & 1.46 & 0.126 & 0.009 \\
D & Kucchan & 1.34 & 0.170 & 0.025 \\
\hline
\end{tabular}

denote effective mean principal stress and principal stress difference, respectively. Solid line in the figure is the effective stress path, which is called in this paper as static stress path, calculated by Cam-clay model proposed by Roscoe et al. (1963). Soil parameters used for the calculation are obtained by another series of conventional consolidated undrained triaxial tests and shown in Tabe 5 (See Appendix). Although the stress points for the end of relaxation in all tests, except for some short duration test cases of Sample $B$, lie below the solid line, stress points corresponding to the time $t_{s}$ locate close to the static stress path. For Sample A, stress points corresponding to the limiting equili- 


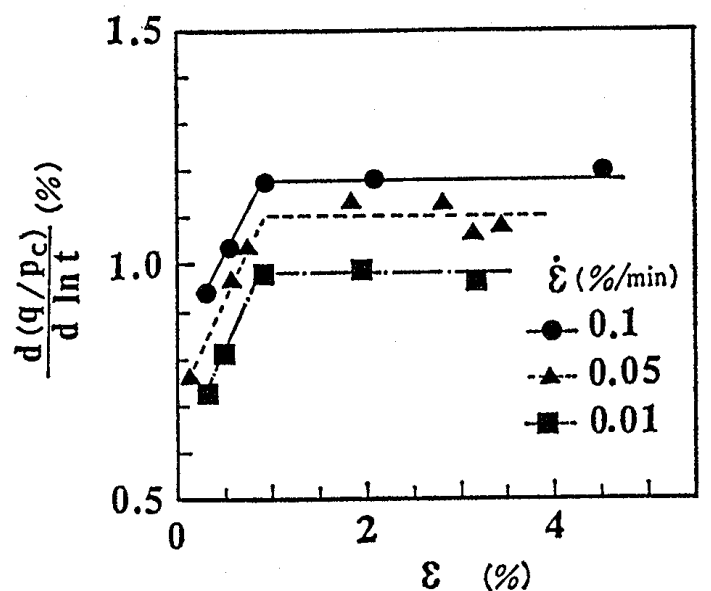

(a) Sample A

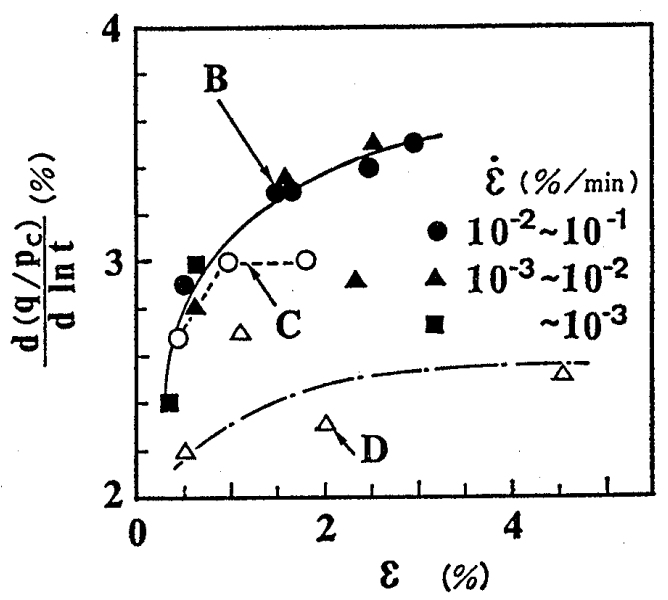

(b) Sample B, C and D

Fig. 5. Rate of stress relaxation vs. initial strain relationship

brium stress state, which is almost the same as the end of relaxation test, make a curved line similar to the static stress path. Matsui et al. (1986) defined the stress path corresponding to the limiting state of stress as to be the equilibrium state surface in their elasto-viscoplastic constitutive equation. The present authors wish to continue research to make clear the relationship between the limiting equilibrium state in the relaxation test and that in the creep test.

The relationship between initial slope of straight line in Fig. 3 and initial strain imposed prior to the relaxation test is shown in Fig. 5. The slope of the straight line increases with initial strain for Sample $B$ as reported earlier by Murayama and Shibata (1964), whereas the slope becomes constant above a certain value of strain for Sample A,

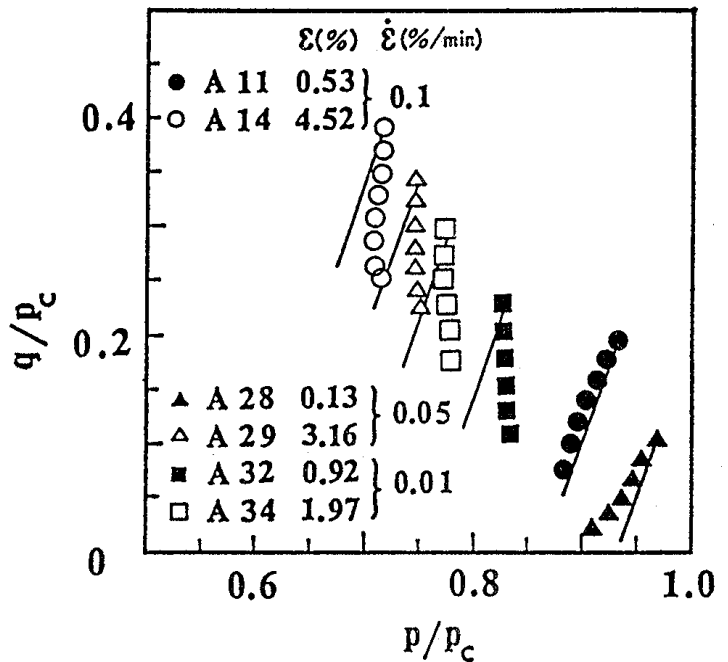

Fig. 6. Effective stress path during stress relaxation

$\mathrm{C}$ and $\mathrm{D}$ as shown by Akai et al. (1975). For sample B, in which the rate of strain prior to the relaxation test is varying with time during constant rate of stress loading and creep loading, the slope of the stress difference versus logarithm of time curve is almost independent of the rate of strain. On the contrary, a trend that the slope increases with the rate of strain is observed for sample A.

Pore Water Pressure Change during Relaxation

On the behavior of pore water pressure during stress relaxation, different conclusions have been derived by different researchers as described in earlier section in this paper.

Fig. 6 illustrates the effective stress path during relaxation test for Sample $\mathrm{A}$ in $p-q$ stress space. Solid line in the figure is the line pararell to the total stress path. If pore pressure does not change during relaxation test, effective stress point goes down along this line. As can be seen from this figure, pore water pressure increases when the imposed initial strain is small and vice versa. When the rate of strain is small, effective stress point goes downward in almost pararell to the longitudinal axis. As the total mean principal stress decreases with the principal stress difference during relaxation process, the plastic pore pressure $\Delta u_{s p}$ proposed by Lo 


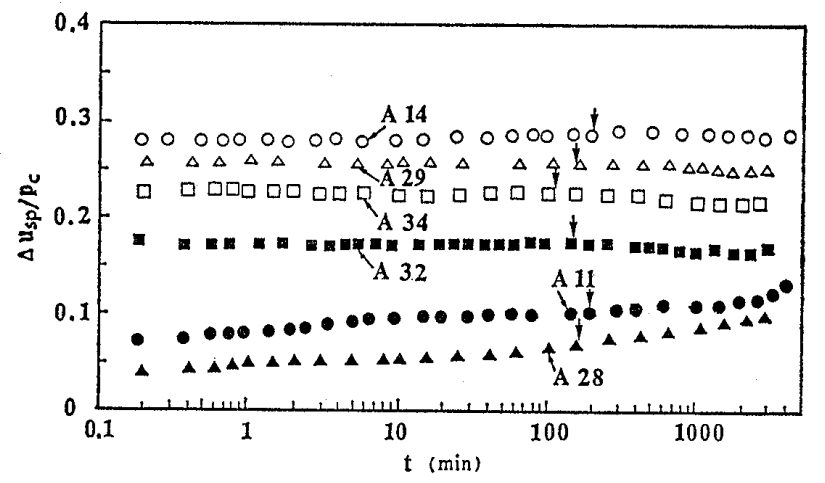

(a) Sample A

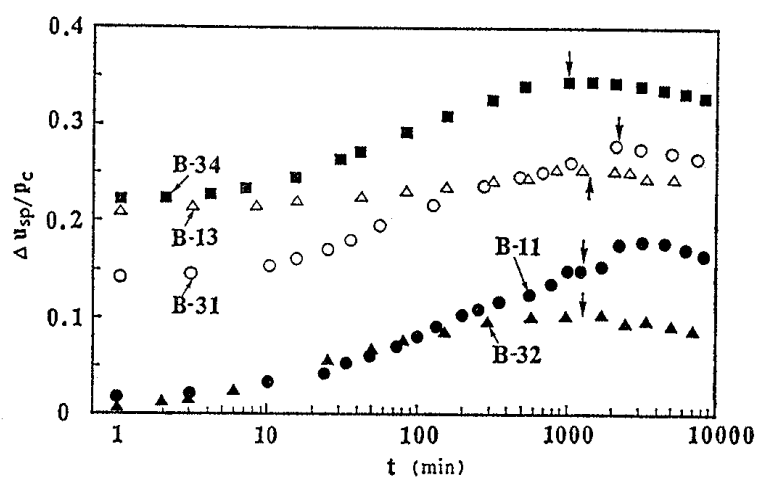

(b) Sample B

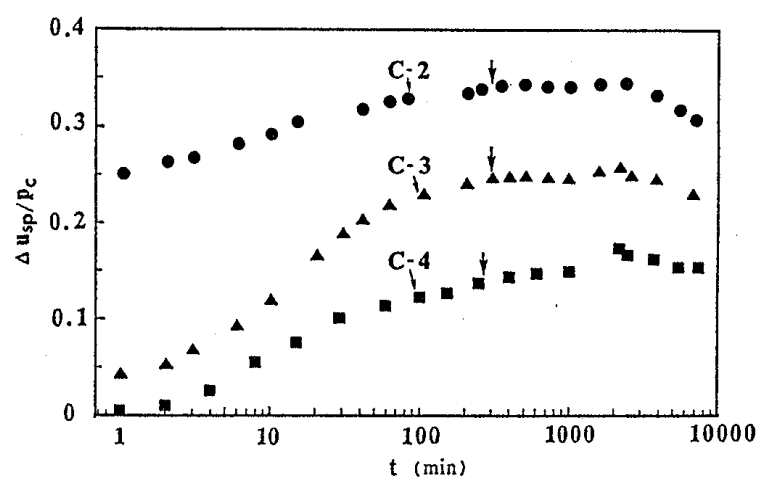

(c) Sample C

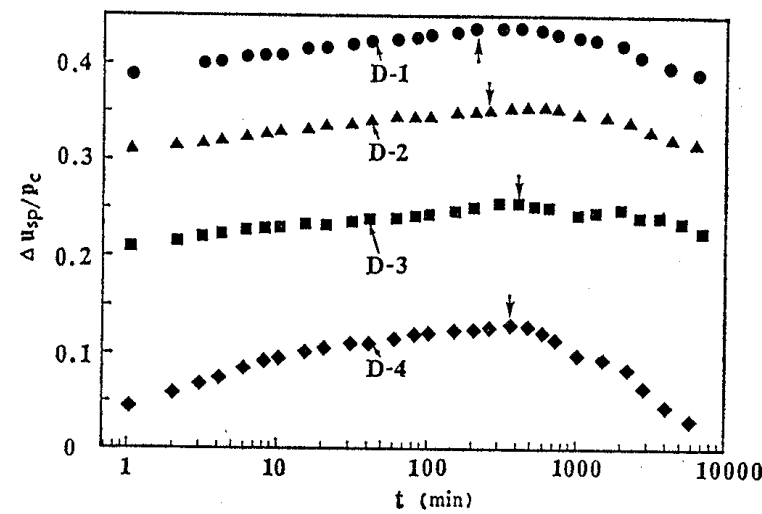

d) Sample D

Fig. 7. Change of plastic component of pore water pressure during stress relaxation

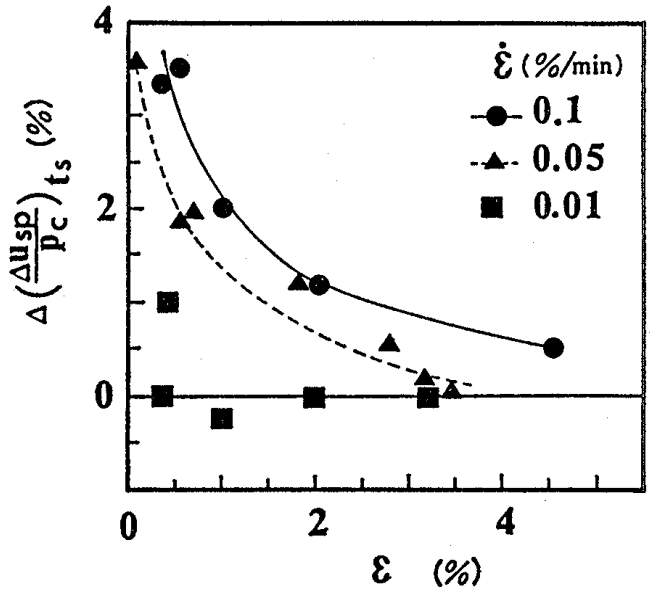

(a) Sample A

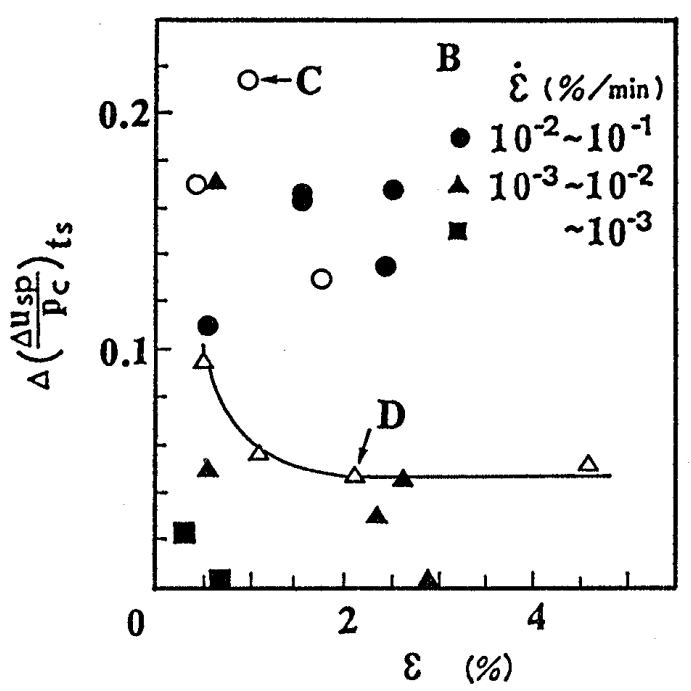

(b) Sample B,C and D

Fig. 8. Increment of plastic component of pore water pressure vs. initial strain relationship

(1969), which is given by the following equation, is used in this paper to explain the pore pressure behavior during stress relaxation.

$$
\Delta u_{s p}=\Delta u-\Delta \sigma_{m}
$$

where, $\Delta u$ and $\Delta \sigma_{m}$ are induced total pore water pressure and mean principal stress in terms of total stress, respectively.

Plastic pore pressure versus logarithm of time relationship is shown in Fig. 7. Arrows in the figure correspond to the time $t_{s}$ in Fig. 3. Fig. 8 illustrates the relationship between the normalized plastic pore pressure increment developed from the start of relaxation test to the time $t_{s}$ and axial strain imposed in the preceding undrained loading 
process. For Samples A and B, the relationship is shown for various strain rate. It is seen from this figure that the development of plastic pore pressure decreases with the increase in the initial strain level for the same strain rate, and it increases with the increase in the strain rate for the same strain level. Thus the behavior of pore water pressure depends both on the strain level and strain rate prior to the relaxation test.

Arai (1985) suggested that when the strain rate at the beginning of the relaxation test is large, non-uniform distribution of pore pressure develops within the specimen and the equalization occurs during relaxation process. Strain rate in this experiment, however, is considered in the light of previous investigaion (e. g. JSSMFE, 1979) to be smaller enough to develop uniform pore pressure distribution. It has been known that the pore pressure increases during isotropic stress relaxation due to the reorientation of clay particles (Arulanandan et al. 1971). Similar behavior may occur during relaxation of principal stress differnce. If it is assumed that the time dependent pore pressure develops durin gundrained shear prior to the relaxation test, the magnitude of development of that may be larger for smaller strain rate. Therefore, when the rate of strain is large and the development of the time dependent pore pressure is small during undrained loading, pore pressure increase during relaxation process may become large.

The influence of the strain level on the pore pressure increase during relaxation test is considered as follows. As can be seen from the pore pressure versus axial strain relationship during undrained shear, the smaller the strain level, the larger the increment of pore pressure. Thus, the trend of the development of pore pressure during shear is larger for smaller strain level and the trend may emerge in the relaxation process.

\section{CONCLUSIONS}

From the results of undrained stress relaxation tests on four saturated remoulded clays consolidated under isotropic stress condition, the following conclusions are obtained.

(1) Principal stress difference versus logarithm of time relationship is approximated by two straight lines irrespective of strain rate, strain level and the mode of stress application, and the stress state corresponding to the intersection of the two lines locates close to the effective stress path, which is called in this paper as static stress path, calculated by Cam-clay model of Rescoe et al.

(2) A sign of the existence of a limiting equilibrium stress is found for Sample $A$ and the effective stress state at that time lies below the static stress path mentioned above and makes a curve similar to the path.

(3) The slope obtained from the principal stress difference versus logarithm of time curve depends on the axial strain level prior to the relaxation test.

(4) Plastic component of pore pressure during stress relaxation depends both on the strain rate and strain level imposed in the preceding undrained loading.

\section{ACKNOWLEDGMENTS}

The authors wish to thank Messrs. Y. Osanai, T. Kabasawa, I. Ogata, K. Okuda and Y. Kudoh for their experimental assistance.

Financial support of Grant-in Aid for Encouragement of Young Scientists (No. 62750456) and for General Scientific Research (No.62550353) from the Ministry of Education, Science and Culture is also greatly acknowledged.

\section{NOTATION}

$$
\begin{aligned}
p= & \text { effective mean principal stress } \\
p_{c}= & p \text { after consolidation } \\
q= & \text { principal stress difference } \\
q_{\mathrm{max}}= & \text { maximum principal stress difference ( } q \text { at } \\
& \text { failure }) \\
q_{0}= & q \text { at the start of stress relaxation } \\
\Delta u_{s p}= & \text { plastic component of pore pressure develo- } \\
& \text { ped during undrained test } \\
t_{s}= & \text { time corresponds to the inflection point in } \\
& \text { the principal stress difference versus logar- }
\end{aligned}
$$


ithm of time curve during stress relaxation $\varepsilon=$ axial strain

$\dot{\varepsilon}=$ strain rate

$\eta=$ stress ratio $(=q / p)$

$\kappa, \lambda=$ swelling and compression indices in terms of natural logarithm

$M=\eta$ at the critical state

\section{REFERENCES}

1) Akai, K., Adachi, T. and Ando, N. (1975): "Existence of a unique stress-strain-time relation of clays," Soils and Foundations, Vol.15, No. 1, pp. 1-16.

2) Arai, K. (1985): "Representation of soft clay behavior based on minimization of dissipated energy," Proc., 5 th ICONMIG, pp. 277-284.

3) Arulanandan, K., Shen, C. K. and Young, R. B. (1971): "Undrained creep behavior of a coastal organic silty clay," Geotechnique, Vol. 21, No. 4, pp. 359-375.

4) Christensen, R.W. and Wu, T.H. (1964): "Analysis of clay deformation as a rate process," Proc., ASCE, Vol.90, No. SM 6, pp. 125157.

5) Japanese Society of Soil Mechanics and Foundation Engineering (1979): "Method for consolidated-undrained triaxial compression test on soils, "Method of Testing Soils, p.6.4.16. 4.42 .

6) Lacerda, W. A. and Houston, W. N. (1973): "Stress relaxation in soils," Proc., 8 th ICSMFE, Vol. 1, pp. 221-227.

7) Lo, K. Y. (1969) : "The pore pressure-strain relationship of normally consolidated undisturbed clays," Canadian Geotechnical Journal, Vol.6, No. 4, pp. 383-412.

8) Matsui, T., Abe, N., Hayashi, K. and Nakano, M. (1986): "Time-dependent characteristics of normally consolidated clay based on flow surface model", Proc., 21 th Japan National Conf. SMFE, pp. 465-466 (in Japanese).

9) Murayama, S. and Shibata, T. (1961) : "Rheological properties of clays," Proc., 5 th ICSMFE, Vol. 1, pp. 269-273.

10) Murayama, S. and Shibata, T. (1964): "Flow and stress relaxation of clays," Rheology and Soil Mechanics, IUTAM Symposium, Grenoble, pp. 99-129.

11) Oda, Y. and Mitachi, T. (1987) : "Stress-straintime behavior of normally consolidated clay," Technical Report, JSSMFE, Hokkaido Branch, No. 27, pp. 67-74 (in Japanese).

12) Roscoe, K. H., Schofield, A. N. and Thurairajah, A. (1963): "Yielding of clays in states wetter than critical," Geotechnique, Vol.13, No.3, pp. 211-240.

13) Vialov, S.S. and Skibitsky, A.M. (1961): "Problems of the rheology of soils," Proc. 5 th ICSMFE, Vol. 1, pp. 387-391.

14) Wu, T. H., Douglas, A. G. and Goughnour, R. D. (1962): "Friction and cohesion of saturated clays," Proc., ASCE, Vol.88, No.SM 3, pp.132 .

\section{APPENDIX}

The soil parameters for Cam-clay model in Table 5 were determined as follows.

Fig. A-1 illustrates the isotropic consolidation and swelling test results for four samples. Compression index $\lambda$ and swelling index $\kappa$ for each sample were determined from this figure.

The effective stress paths and the stress ratio versus strain relationships obtained from the conventional consolidated undrained triaxial compression test with the strain rate of $0.04 \% / \mathrm{min}$ are shown in Fig. A-2(a) and (b). The stress ratio $M$ at the critical state was determined from these figures. Calculated stress paths and stress ratio versus strain curves by Cam-clay model are also shown in the figures. As the effective stress path defined by Cam-clay model is assumed to be the static equilibrium stress states when the strain rate is zero, the experimental stress

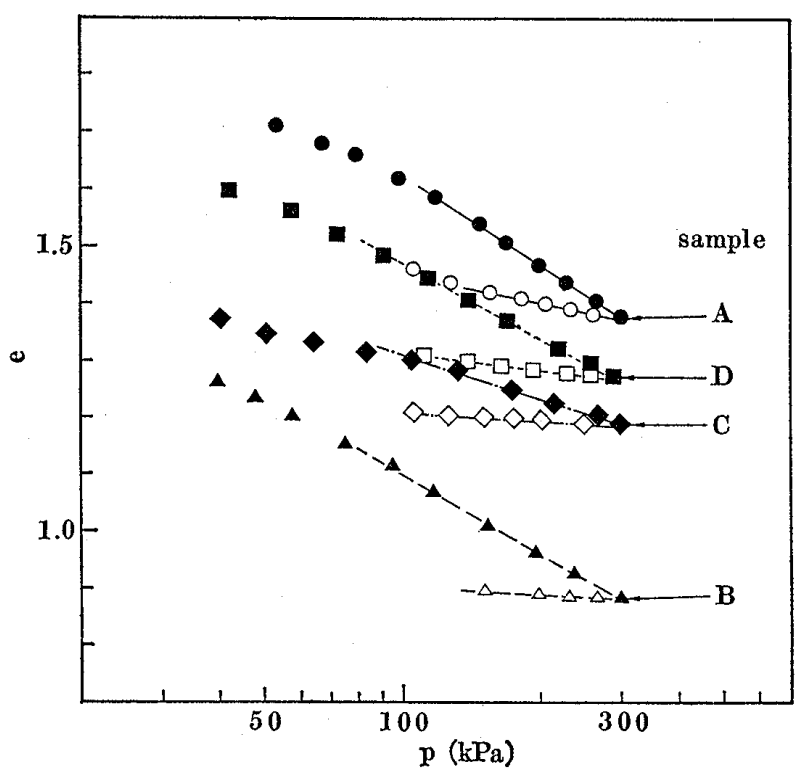

Fig. A-1. Isotropic consolidation and swelling test results 
paths locate right hand side of the calculated ones. Observed stress ratio versus strain relationships for Sample A and B agree fairly

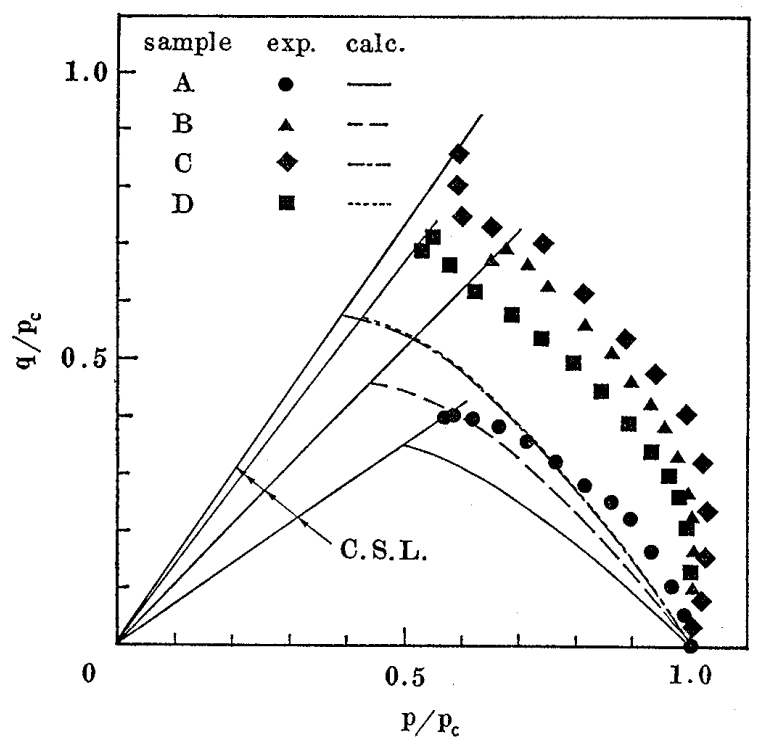

(a) Effective stress paths well with the calculated ones, whereas Camclay model underestimates the strain for other two samples.

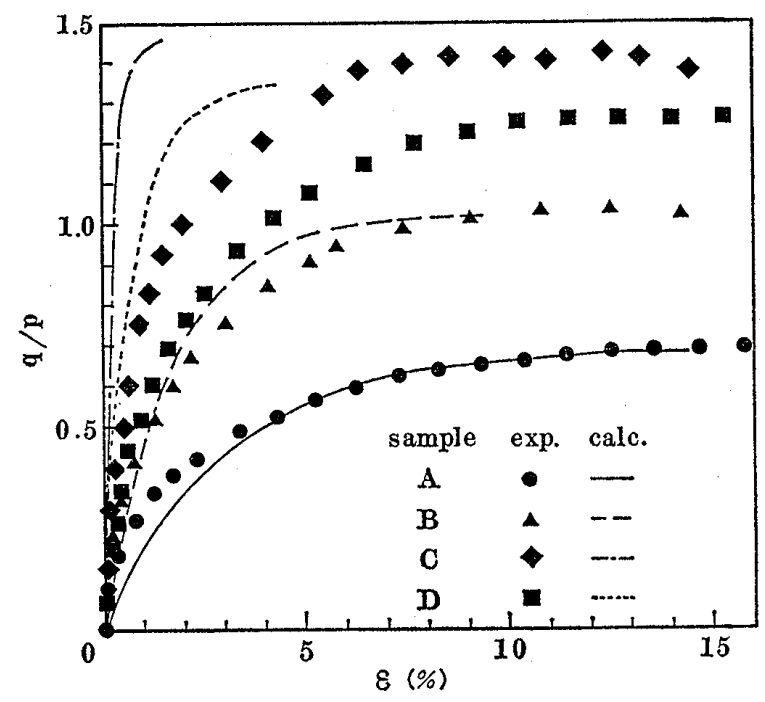

(b) Stress ratio vs. strain relationships Fig. A-2. Conventional consolidated undrained triaxial test results 